Article

\title{
Fungi Associated with Horse-Chestnut Leaf Miner Moth Cameraria ohridella Mortality
}

\author{
Irena Nedveckytè ${ }^{1, *}$, Dalè Pečiulytè ${ }^{2}$ and Vincas Būda ${ }^{2}$ \\ 1 Institute of Biosciences, Life Sciences Center, Vilnius University, Saulètekio ave. 7, LT-10257 Vilnius, Lithuania \\ 2 Institute of Ecology, Nature Research Centre, Akademijos 2, LT-08412 Vilnius, Lithuania; \\ dale.peciulyte@gmail.com (D.P.); vincas.buda@gamtc.lt (V.B.) \\ * Correspondence: irena.nedveckyte@gf.vu.lt
}

check for

updates

Citation: Nedveckytè, I.; Pečiulytè, D.;

Būda, V. Fungi Associated with Horse-Chestnut Leaf Miner Moth Cameraria ohridella Mortality. Forests 2021, 12, 58. https://doi.org/ 10.3390/f12010058

Received: 14 December 2020 Accepted: 31 December 2020 Published: 5 January 2021

Publisher's Note: MDPI stays neutral with regard to jurisdictional clai$\mathrm{ms}$ in published maps and institutional affiliations.

Copyright: $(\odot 2021$ by the authors. Licensee MDPI, Basel, Switzerland. This article is an open access article distributed under the terms and conditions of the Creative Commons Attribution (CC BY) license (https:// creativecommons.org/licenses/by/ $4.0 /)$.

\begin{abstract}
The total mortality of the leaf-miner horse-chestnut pest, Cameraria ohridella, collected in nature, and the mortality associated with mycoses were assessed under laboratory conditions in stages: for eggs mortality rates of $9.78 \%$ and $61.97 \%$ were found, respectively; for caterpillars, $45.25 \%$ and $5.59 \%$, respectively; and for pupae $21.22 \%$ and $100 \%$, respectively. At the egg stage, Cladosporus cladosporioides caused mycosis most often (27\% of all mycoses); at the caterpillar stage there was no pronounced predominant fungus species; at the pupal stage both Cordyceps fumosorosea and Beauveria bassiana (32\% and 31\%, respectively) were most dominant; whereas at the adult stage Lecanicillum aphanocladii (43\%) were most dominant. C. ohridella moths remained the most vulnerable during the pupal and caterpillar stages. Maximum diversity of fungi associated with the leaf-miner moth was reached during the period of development inside the chestnut leaf (Shannon-Wiener index $-H^{\prime}=2.608$ at the caterpillar stage, $H^{\prime}=2.619$ at the pupal stage), while the minimum was reached in the adult stage $\left(H^{\prime}=1.757\right)$. In the caterpillar and pupa stages, saprophytic fungi were most often recorded. Comparative laboratory tests revealed novel properties of the fungus L. aphanocladii, its effectiveness as the leaf-miner moth's entomopathogen and its suitability for field application trials while developing environment-friendly methods for horse-chestnut pest control.
\end{abstract}

Keywords: leaf miner; Cameraria ohridella; entomopathogenic fungi; Lecanicillium aphanocladii

\section{Introduction}

Horse-chestnut, Aesculus hippocastanum L. (Hippocastanaceae), is widely grown all over Europe in urban greenery, but since the 1980s the decorative value of these trees has fallen sharply due to the spread of the leaf-mining pest Cameraria ohridella Deschka and Dimic (Lepidoptera, Gracillariidae). Cameraria ohridella causes large-scale browning of leaves and pre-mature defoliation of horse-chestnut trees [1-5]. During the last 30 years, the leafminer spread over Europe, reaching Russia and Turkey [6]. In Lithuania, C. ohridella was registered for the first time in 2002 [7] and since then it has dispersed to a great extent and causes multiple infestations annually [8]. The moth's region of origin was obscure for a long time; however based on DNA analysis, the Balkan origin of the C. ohridella was revealed [9], and the species has been attributed to invasive ones in many countries. The horse-chestnut leaf miner has been widely studied, including moth biology and distribution [10-14], potential predators [15-18] and competition either with native leaf miners [19] or phytopathogenic fungi [20].

Control of C. ohridella populations is complicated due to the lifestyle of the pest: caterpillars develop inside the leaves [13] and host plants occur in urban territories where application of insecticides is unsuitable. The removal of the steadied leaves beneath the trees and subsequently either composting or burning reduces populations of natural enemies (Chalcidoides species) [21]. Application of systemic chemicals (e.g., imidacloprid, abamectin) by injection into the trunk of a tree is effective; however, wounds facilitate plant pathogen invasions and damages $[22,23]$. Removal of the adult moths with sticky 
pheromone traps $[17,23-25]$ can decrease pest populations; however, it is expensive and requires a large amount of effort and manual work.

In our opinion, the search for host-specific antagonists should be a priority. However, information on C. ohridella-related fungal entomopathogens remains scarce, and most investigations of fungi involved in moth mortality have been performed in a single country only, namely in the Czech Republic [26-30]. Fungi belonging to the genera of known fungal entomopathogens (Beauveria Vuill., Lecanicillium W. Gams and Zare, Metarhizium Sorokin, and Paecilomyces Bainier) were isolated from C. ohridella habitat and some strains showed entomopathogenic activity against pupae and moth caterpillars [31-35]. Unfortunately, information on fungi virulence throughout moths' developmental stages remains scarce.

The aim of the present study was to identify fungal entomopathogens associated with C. ohridella during all developmental stages, from eggs to pupae. The following tasks were set: (a) to examine diseased $C$. ohridella adults, collected from different $A$. hippocastanum trees; (b) to establish the mortality of $C$. ohridella eggs, caterpillars and pupae collected from the field focusing on fungi; (c) to isolate and identify fungi recovered from cadavers; (d) to carry out comparative efficiency tests of dominant fungus species in comparison with C. ohridella at different developmental stages.

\section{Materials and Methods}

\subsection{Insects}

Trunk and leaves from a lower crown of trees were examined mid-May to end-May, mid-August to mid-September and at leaf fall periods during 2009-2011, i.e., during the periods of the first and the second generations of $C$. ohridella. Each cadaver of adult moths (mainly found on tree trunks) was placed in a sterile Petri dish individually. Leaves were collected from five heavily infested, randomly selected trees (30 leaves per tree).

Leaves (used for egg treatment) were viewed under a stereomicroscope (Labomed Luxeo 2S Stereo Microscope; $\times 10$ magnification) to find and determine segments with moth eggs. Leaf segments $\left(2-3 \mathrm{~cm}^{2}\right)$ with a known number of eggs were cut out and placed in Petri dishes ( $5 \mathrm{~cm}$ diameter) with sterile moistened cotton lumps and sealed with a lid to avoid desiccation. Eggs were incubated in the lab at $20 \pm 2{ }^{\circ} \mathrm{C}$. Up to $150-250$ eggs approximately were collected from each tree. The total number of eggs examined was 1451. After incubation, the total number of emerged caterpillars was counted and the egg mortality percentage was calculated. Eggs from which larvae did not hatch were viewed under the stereomicroscope and a light microscope (Motic B1 Series; $\times 150$ and $\times 1000$ magnifications) to check for possible fungal infection.

\subsection{Isolation of Fungi}

Leaf segments containing mines (each $2.5-3 \mathrm{~cm}^{2}$ in square) were cut out following leaf surface sterilization by application of $0.5 \%(v / v)$ sodium hypochlorite $(\mathrm{NaOCl})$. Each segment was treated with $75 \%$ ethanol for $1 \mathrm{~min}$, followed by immersion for $2 \mathrm{~min}$ in sodium hypochlorite and again for $30 \mathrm{sec}$ in $75 \%$ ethanol. Then, the segments were rinsed three times in sterile distilled water, and each was placed into a separate Petri dish $(5.5 \mathrm{~cm}$ in diameter) supplied with a wet cotton lump. Dishes were sealed and incubated at $20 \pm 2{ }^{\circ} \mathrm{C}$ in the lab. Dishes were examined daily, and adult moth emergence was recorded. The same procedure was performed for the treatment of overwintered pupae, except that only areas of fully developed winter mines were cut from the leaves. Four replicates were prepared, each containing 30 mines. Mines containing caterpillar (or pupal) cadavers were aseptically dissected; each cadaver was taken out of a mine and placed on the moistened paper within a sterile Petri dish. Dishes were kept at $25^{\circ} \mathrm{C}$ in the dark and examined daily for mycoses. A total of 632 caterpillars and 568 pupae within mines were tested.

Fungi were identified based on their morphology by using a low magnification stereomicroscope $(\times 40$ magnification $)$ and by preparing slides for light microscopy $(\times 400$ and $\times 1000$ magnifications). In cases when a fungi mycelium covered a cadaver and it did not produce conidia (or spores), small segments were dissected and plated on a half-strength 
Potato Dextrose Agar (PDA) media supplemented with chloramphenicol $\left(0.1 \mathrm{~g} \mathrm{~L}^{-1} w / v\right)$, and sub-cultured on three media: PDA, Sabouroud Dextrose Agar (SDA) and Czapek Dox Agar (CDA) (all from Liofilchem, Italy). Identification of fungi followed standard methods based on macro- and micro-morphological features [36-43]. All fungi species' names were revised according to http:/ /www.indexfungorum.org/.

\subsection{Insect Susceptibility to Fungi}

\subsubsection{Fungi and Conidia Preparation}

Four species of entomopathogenic fungi were used for comparative bioassay trials against C. ohridella: Beauveria bassiana (Bals.-Criv) Vuill., Cordyceps fumosorosea (Wize) Kepler, B. Shrestha and Spatafora (syn., Isaria fumosorosea), Lecanicillium aphanocladii Zare and W. Gams and Lecanicillium psalliotae (Treschew) Zare and W. Gams. All fungal strains are maintained in the Microorganisms Culture Collection at the Biodeterioration Research Laboratory of Nature Research Centre (Vilnius, Lithuania). The tested fungi were grown for 12-14 days on PDA plates; conidia were washed with $1 \mathrm{~mL}$ Tween 80 solution $(0.01 \%, v / v)$. Three plates of each fungus were washed; washings were mixed and conidia suspension was adjusted to the desired concentration using a haemocytometer. Germination of conidia was over $95 \%$. Cameraria ohridella eggs, naked pupae, and pupae inside the mines were treated with entomopathogenic fungi conidia suspensions at a concentration of $3 \times 10^{8}$ conidia $\mathrm{mL}^{-1}$.

\subsubsection{Egg Trials}

Leaf segments $(3 \times 3 \mathrm{~cm})$ with a counted number of eggs were cut out of a leaf, and their surfaces were gently sterilized, placed into Petri dishes and sprayed with $1.5 \mathrm{~mL}$ of the appropriate fungus conidial suspension at $3 \times 10^{8}$ conidia $\mathrm{mL}^{-1}$ concentration. Control Petri dishes were sprayed with $1.5 \mathrm{~mL}$ of distilled water. Leaf segments contained a different number of eggs (from 22 to 87 ); therefore, two or three segments were placed per dish to obtain $\sim 100$ eggs for each trial and each control. Each conidial concentration and control was tested three times ( $\sim 100$ eggs per replication, i.e., $\sim 300$ eggs in the test and $\sim 300$ eggs in control in total). Dishes with eggs were sealed and incubated for $3-5$ days under $20 \pm 2{ }^{\circ} \mathrm{C}$ in the laboratory. Emerged caterpillars were counted daily.

\subsubsection{Pupae Trials}

Fallen tree leaves containing overwintered $C$. ohridella mines were washed with a large amount of water and dried-up. Leaf pieces containing mines were cut out (mine area only) and leaf surfaces were sterilized. Half of the sterilized pieces with mines were used directly for bioassay. The other half was aseptically opened; pupae were taken out and used for naked pupae bioassay. In each replicate, 30 pupae were placed on filter paper in a Petri dish $(8.5 \mathrm{~cm}$ diameter) and sprayed with $1.5 \mathrm{~mL}$ of the conidia suspension of the appropriate fungus at a $3 \times 10^{8}$ conidia $\mathrm{mL}^{-1}$ concentration. Control pupae were sprayed with the same volume of distilled water. Five replicates were tested. Pupae were incubated for 4 weeks in a humid chamber at 95\% RH (high relative humidity was required to avoid desiccation of pupae) and $22 \pm 2{ }^{\circ} \mathrm{C}$. Pupae were examined weekly and emerged adults were counted.

\subsection{Data Analyses}

To evaluate fungal species diversity at each stage of the leaf-miner moth, the ShannonWiener index $\left(H^{\prime}\right)$ was used [44]: $H^{\prime}=-\sum_{i=1}^{S}\left(p_{i} \ln p_{i}\right)$, where $S$ is the total number of species recorded and $p_{i}$ is the frequency of occurrence of the $i$ th species. Mortality percentage of the control was calculated, and the mean value of the five replicates (30 individuals each; total $n=150$ ) was presented, as well as standard error (SE). The mortality percentages of insects were normalized using $\arcsin (\sqrt{x / 100})$ transformation prior to the analysis of variance. Differences in the mean mortality percentage of the insect between different fungi trials, as well as between certain fungus trials and controls (untreated with fungi) were ascertained by variance analysis (one-way ANOVA) followed 
by multiple comparisons of the means conducted using Tukey's test (SPSS 16 statistical package).

\section{Results}

\subsection{Fungi Associated with C. ohridella Mortality \\ 3.1.1. Adult Moths' Mycoses}

Five samplings resulted in a collection of 349 adult moth cadavers, 109 of which had mycosis symptoms (Table 1). During incubation in the laboratory, mycelium development on the cadavers was species-dependent, and started after 2-3 days of incubation, reaching maturity within a week. Fungi were assigned to nine species from seven genera (Table 1). Lecanicillium aphanocladii was the most common species with $39.45 \%$ frequency of occurrence $(\mathrm{FO})$, followed by L. psalliotae $(\mathrm{FO}=16.51 \%$ ) and Trichothecium roseum (Pers.) Link $(\mathrm{FO}=15.6 \%)$. The fungi species diversity index for adult moth cadavers was $H^{\prime}=1.757$.

Table 1. Mycosis symptoms of Cameraria ohridella at different stages: from egg to adult.

\begin{tabular}{|c|c|c|c|c|}
\hline & Adult Moths & Eggs & Caterpillars & Pupae \\
\hline Total number (TN) of specimen tested & 349 & 1451 & 632 & 568 \\
\hline $\mathrm{TN}$ (and \%) of dead individuals & $349(100)$ & $142(9.78)$ & $286(45.25)$ & $183(21.22)$ \\
\hline $\mathrm{TN}$ (and \%) with mycosis symptoms & $109(31.23)$ & $88(61.97)$ & $36(5.59)$ & $183(100)$ \\
\hline \multirow{2}{*}{ Fungi species } & \multicolumn{4}{|c|}{ Number of infected individuals and FO * } \\
\hline & Adult moths & Eggs & Caterpillars & Pupae \\
\hline Akanthomyces lecanii (Zimm.) Spatafora, Kepler and B. Shrestha & & & & $9(4.91)$ \\
\hline Alternaria alternata (Fr.) Keissl. & & & $2(5.56)$ & $7(3.82)$ \\
\hline Aspergillus parasiticus Speare & & & $2(5.56)$ & $3(1.64)$ \\
\hline Beauveria bassiana (Bals.-Criv.) Vuill. & $6(5.5)$ & $11(12.5)$ & $3(8.33)$ & $31(16.94)$ \\
\hline Cladosporium cladosporioides (Fresen.) G.A. de Vries & $11(10.09)$ & $27(30.68)$ & $3(8.33)$ & $11(6.01)$ \\
\hline Clonostachys rosea (Link) Schroers, Samuels, Sefert and W. Gams & & & & $8(4.37)$ \\
\hline Colletotrichum gloeosporioides (Penz.) Penz. and Sacc. & $2(1.84)$ & $1(1.14)$ & $2(5.56)$ & \\
\hline Cordyceps fumosorosea (Wize) Kepler, B. Shrestha and Spatafora & $3(2.75)$ & $2(2.27)$ & & $32(17.49)$ \\
\hline Cordyceps farinosa (Holmsk.) Kepler, B. Shrestha and Spatafora & & $3(3.41)$ & & $6(3.28)$ \\
\hline Cordyceps tenuipes (Peck) Kepler, B. Shrestha and Spatafora & & & & $4(2.19)$ \\
\hline Erysiphe flexuosa (Peck) U. Braun and S. Takam. & & & $3(8.33)$ & \\
\hline Fusarium proliferatum (Matsush.) Nirenberg & $2(1.84)$ & & & $4(2.18)$ \\
\hline Fusarium oxysporum Schltdl. & & $6(6.82)$ & & $3(1.64)$ \\
\hline Fusarium fujikuroi Nirenberg & $7(6.42)$ & & $1(2.77)$ & \\
\hline Harzia acremonioides (Harz) Costantin & & & $2(5.56)$ & \\
\hline Lecanicillium aphanocladii Zare and W. Gams & $43(39.45)$ & $13(14.77)$ & $2(5.56)$ & $2(1.09)$ \\
\hline Lecanicillium psalliotae (Treschew) Zare and W. Gams & $18(16.51)$ & $4(4.55)$ & & $16(8.74)$ \\
\hline Metarhizium anisopliae (Metschn.) Sorokin & & & & $4(2.19)$ \\
\hline Microascus brevicaulis S.P. Abbott & & & & $2(1.09)$ \\
\hline Oedocephalum glomerulosum (Bull.) Sacc. & & & $3(8.33)$ & \\
\hline Penicillium citrinum Thom & & $5(5.68)$ & $1(2.77)$ & \\
\hline Penicillium chrysogenum Thom & & $2(2.27)$ & $1(2.77)$ & \\
\hline Penicillium oxalicum Currie and Thom & & $4(4.55)$ & & $2(1.09)$ \\
\hline Sarocladium strictum (W. Gams) Summerb. & & & $4(11.12)$ & $16(8.74)$ \\
\hline Stachybotrys chartarum (Ehrenb.) S. Hughes & & & & $3(1.64)$ \\
\hline Trichoderma harzianum Rifai & & $2(2.27)$ & $2(5.56)$ & $4(2.18)$ \\
\hline Trichothecium roseum (Pers.) Link & $17(15.6)$ & $8(9.09)$ & $5(13.89)$ & \\
\hline Other (unidentified four morphotypes) & & & & $16(8.74)$ \\
\hline Total number of species & 9 & 13 & 15 & 19 \\
\hline Total number of genera & 7 & 9 & 14 & 15 \\
\hline Shannon-Wiener diversity index $\left(H^{\prime}\right)$ & 1.757 & 2.174 & 2.608 & 2.619 \\
\hline
\end{tabular}

* FO-frequency of occurrence (in brackets) was calculated as the percentage of cadavers with the separate fungus of the total number of cadavers with mycosis symptoms. 


\subsubsection{Egg Mortality and Mycoses}

A total of 1451 eggs were incubated and checked for hatching daily in the laboratory. The eggs started hatching within two days of incubation and hatched approximately after a week. Only $9.78 \%$ of the eggs (142 out of 1451 incubated) did not hatch; growth of fungi was detected on $61.97 \%$ of the unhatched eggs and on $6.06 \%$ of all eggs (88 out of 142 and out of 1451, respectively) (Table 1). In total, 13 fungi species from nine genera were identified. The species diversity index $H^{\prime}$ of fungi found on C. ohridella eggs was equal to 2.174. Cladosporium cladosporioides was the most frequent isolate (recovered from $30.68 \%$ of unhatched eggs), followed by L. aphanocladii (14.77\%) and B. bassiana (12.5\%).

\subsubsection{Caterpillar Mortality and Mycoses}

Six hundred thirty-two caterpillars inside the mines were incubated in the laboratory. During the first three days, only 19 (3.0\%) dead caterpillars were registered. Mortality of caterpillars reached $4.6 \%$ within $6 \mathrm{~d}$, and $5.9 \%$ within $9 \mathrm{~d}$ of incubation. During two weeks of rearing, only $54.75 \%$ of the caterpillars (346 out of 632 incubated) reached the adult moth stage, and thus the total caterpillar mortality was considered as being high. Mortality of $5.59 \%$ (36 out of 286) caterpillars was induced by fungi. The fungi species diversity index $\left(H^{\prime}=2.608\right)$ determined for the caterpillars was higher than that for the adult moths $\left(H^{\prime}=1.757\right)$. The frequency of occurrence of any fungus species ranged from $2.77 \%$ to $13.89 \%$ (Table 1). Trichothecium roseum $(\mathrm{FO}=13.89 \%)$, Sarocladium strictum $(\mathrm{FO}=11.12 \%)$ and Oedocephalum glomerulosum ( $\mathrm{FO}=8.33 \%$ ) were the most common fungi species isolated. Presence of bacteria and yeasts was noted as well; however those were not analyzed.

\subsubsection{Pupal Mortality and Mycoses}

A total of 568 mines cut from the collected fallen leaves were incubated with overwintered pupae. Adult moths did not emerge from $21.22 \%$ of the pupae (183 emerged out of 568 pupae) (Table 1), and fungi were recovered from all diseased pupae $(100 \%)$. Complexes of fungi species rather than a single species were detected quite often, approximately in $33 \%$ of the diseased pupae. The diversity index of the fungi species isolated from the pupae $H^{\prime}$ was equal to 2.619 , and its value was the highest established in the present analysis. Nineteen fungal species from 15 genera were isolated (Table 1). Cordyceps fumosorosea (recovered from $17.49 \%$ cadavers), B. bassiana (from 16.94\%) and L. psalliotae (from 8.74\%) as well as S. strictum (from $8.74 \%$ cadavers) were the most common fungi species isolated from the diseased pupae.

\subsection{Groups of Fungal Entomopathogens}

Proportions of recovered fungi species grouped according to their ecology are presented in Figure 1. The highest relative abundance of generalist entomopathogenic fungi (GEF) was revealed in cadavers of $C$. ohridella adult moths ( $\sim 65 \%)$. GEF proportion was smaller in pupae, and even smaller in eggs, comprising $46 \%$ and $38 \%$, respectively. As in the case of GEF, the percentage of opportunistic entomopathogenic fungi (OEF) varied depending on the insect development stage. The highest percent of OEF was found in C. ohridella eggs and caterpillars (in $48 \%$ and $33 \%$ of cadavers, respectively), where the lowest abundance of GEF was recorded (38\% and $28 \%$, respectively).

As well as the relative abundance of ecological groups, the number of species within the GEF group varied depending on the moth developmental stage (Table 2). Lecanicillium aphanocladii prevailed among all isolated entomopathogens (28.30\%). Other more common entomopathogenic species isolated were B. bassiana ( $24.06 \%$ of isolates), L. psalliotae (17.93\%) and C. fumosorosea (17.45\%). 


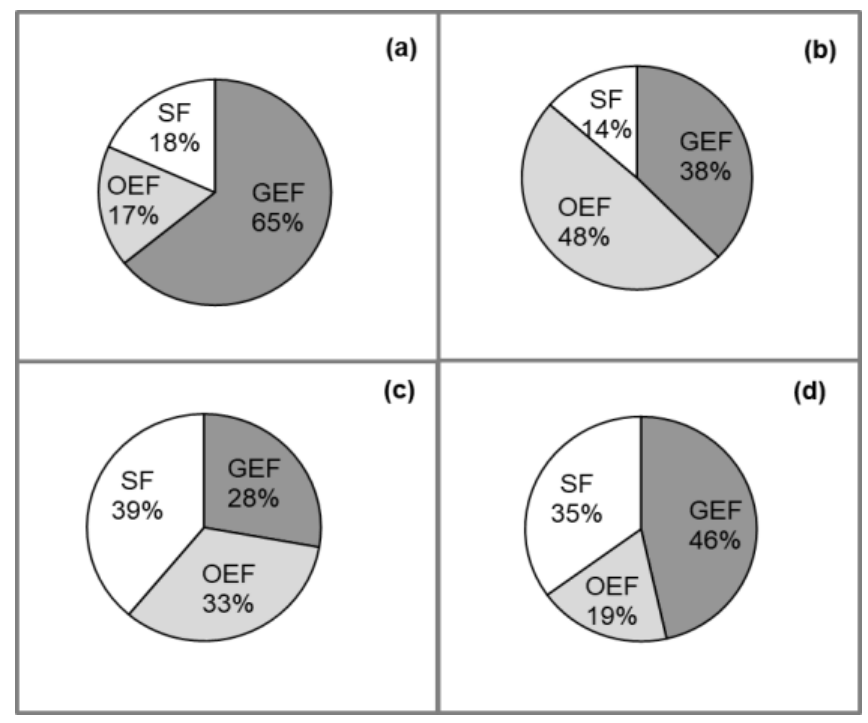

Figure 1. Percentage of generalist entomopathogenic fungi (GEF), opportunistic entomopathogenic fungi (OEF) and other saprotrophic fungi (SF) among the fungi recovered from C. ohridella moths at different stages of development: adult moths (a), eggs (b), caterpillars (c), and pupae (d).

Table 2. Generalist entomopathogenic fungi (GEF) from diseased Cameraria ohridella moths at different developmental stages.

\begin{tabular}{|c|c|c|c|c|c|}
\hline \multirow{2}{*}{ GEF Species } & \multicolumn{4}{|c|}{ Number of Infected Moth Individuals } & \multirow{2}{*}{ Total Number (Percentage, \%) } \\
\hline & Adult & Egg & Caterpillar & Pupae & \\
\hline Akanthomyces lecanii & & & & 9 & $9(4.25)$ \\
\hline Beauveria bassiana & 6 & 11 & 3 & 31 & $51(24.06)$ \\
\hline Cordyceps fumosorosea & 3 & 2 & & 32 & $37(17.45)$ \\
\hline Cordyceps farinosa & & 3 & & 6 & $9(4.25)$ \\
\hline Cordyceps tenuipes & & & & 4 & $4(1.89)$ \\
\hline Lecanicillium aphanocladii & 43 & 13 & 2 & 2 & $60(28.30)$ \\
\hline Lecanicillium psalliotae & 18 & 4 & & 16 & $38(17.93)$ \\
\hline Metarhizium anisopliae & & & & 4 & $4(1.89)$ \\
\hline Total number & 70 & 33 & 5 & 104 & $212(100)$ \\
\hline
\end{tabular}

\subsection{Susceptibility of C. ohridella to Fungal Entomopathogens (Bioassay Tests)}

Of the generalist entomopathogenic fungi, which most often damage C. ohridella at various stages of development in nature (Table 2), four species were selected for a comparative test: B. bassiana, C. fumosorosea, L. aphanocladii and L. psaliotae. The test would have been appropriate for the caterpillar stage of the moth, since this stage is responsible for the damage to the horse-chestnut leaves. However, since caterpillars live inside the leaf, they are very well-protected from any affect, including that of fungi (see Table 2); therefore, the egg and pupal stages of the moth were selected for the comparative analysis.

Lecanicillium aphanocladii was among the most virulent fungi species tested on C. ohridella (Figure 2). These fungi caused mortality of $76.83 \pm 4.1 \%$ eggs and that was 1.8, 2.0, and 2.8 times more compared to the effects caused either by B. bassiana, C. fumosorosea or L. psaliotae, respectively. Beauveria bassiana and C. fumosorosea showed similar virulence towards the eggs: induced mortality reached $57.09 \pm 6.18 \%$ and $53.13 \pm 5.14 \%$, respectively, which was significantly less $(p<0.05)$ from that induced by L. aphanocladii $(76.83 \pm 4.1 \%)$. 


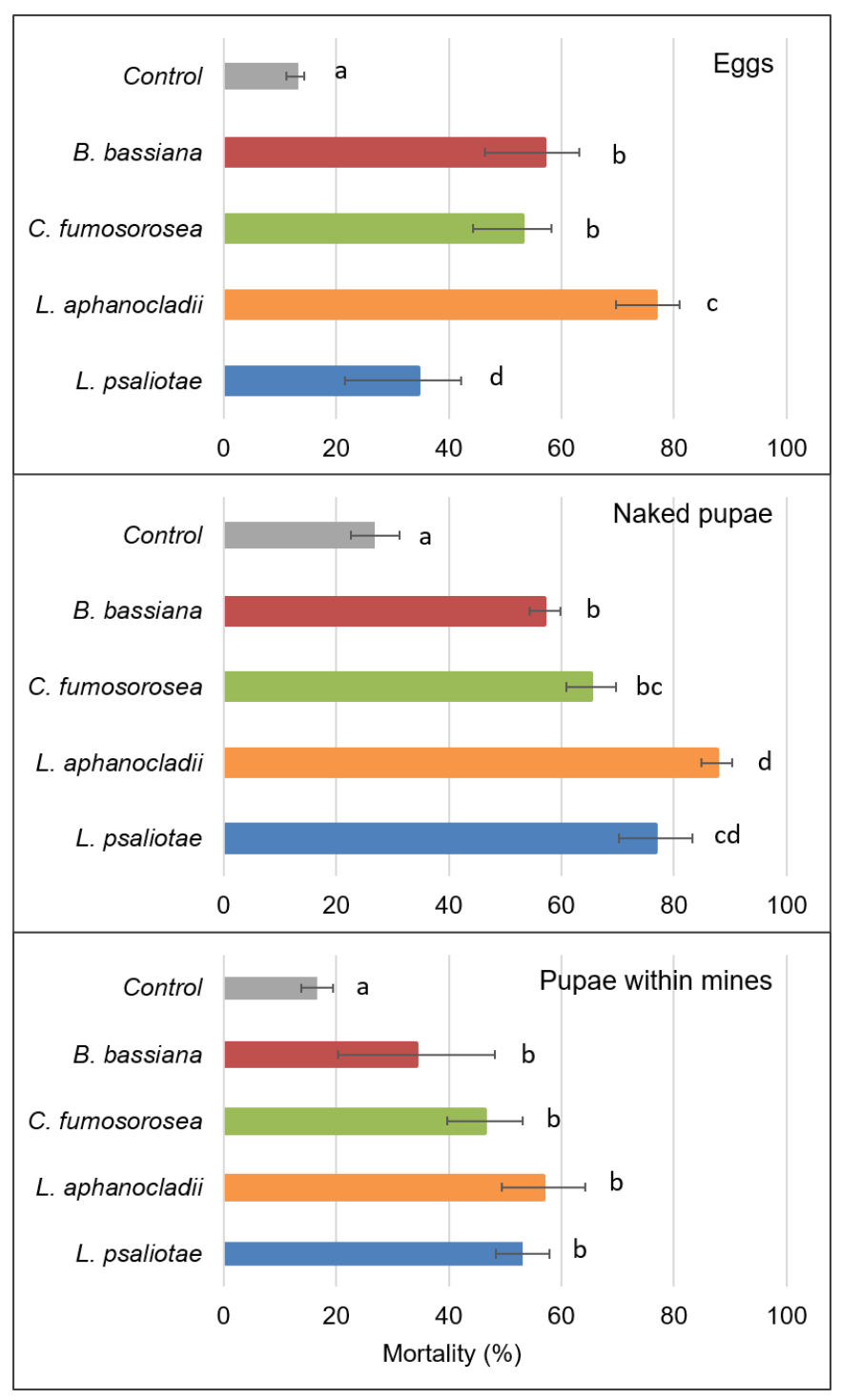

Figure 2. Mortality of $C$. ohridella eggs, naked pupae and pupae within the mines treated with Lecanicillium aphanocladii, L. psalliotae, Beauveria bassiana and Cordyeps fumosorosea at $3 \times 10^{8}$ conidia $/ \mathrm{mL}$ concentrations in the sprayed suspension. Data are presented as the mean of five treatments and standard error (SE) (bars). Different letters at columns indicate statistically significant differences (Tukey's test, $p<0.05$ ).

Mortality of the naked pupae significantly $(p<0.05)$ increased comprising, $57.09 \pm 2.71 \%$, $65.28 \pm 4.39 \%, 76.81 \pm 6.52 \%$ and $87.64 \pm 2.76 \%$, respectively, in the B. bassiana, C. fumosorosea, L. psalliotae and L. aphanocladii treatments. All four tested fungi showed intensive mycelium growth on the cadavers already after 3-4 days of incubation. The lowest mortality was recorded when pupae inside their mines were sprayed with fungal conidia. Mortality following spraying (concentration $3 \times 10^{8}$ conidia $\mathrm{mL}^{-1}$ ), varied from $34.29 \pm 13.91 \%$ to $53.11 \pm 4.79 \%$ in B. bassiana and L. psalliotae treatments, respectively. L. aphanocladii showed a slightly higher virulence trend (56.82 $\pm 7.39 \%)$; however, the difference was not statistically significant $(p>0.05)$.

\section{Discussion}

The analysis of mortality and fungus infestation of the invasive pest leaf miner moth, C. ohridella, collected during various stages of development in nature allows to evaluate the role of entomopathogenic fungi in the regulation of its population. In the present 
study, eggs, caterpillars and pupae were transferred from nature into development-friendly laboratory conditions, and the results both on total mortality and mortality related to mycoses led to lower estimations than those in nature. There is no doubt that longer exposure should increase fungal infection. On the other hand, predators would remove some infected insects and those would not enter the records of the infestation.

The total mortality of C. ohridella eggs was $9.78 \%$, that of larvae was $45.25 \%$ and that of overwintering pupae was $21.22 \%$. There are data on egg and pupae mortality obtained under natural conditions, and the values are much higher, reaching $30 \%$ for eggs [14] and from $53 \%$ up to $97.25 \%$ for overwintered pupae $[5,14,45]$. Unfortunately, due to lack of data both on summer pupae and adults of reproductive age, estimation of general mortality (or survival) throughout the whole life cycle of $C$. ohridella seems not possible. However, there is no doubt that the total survival of preimaginal stages of the moth is very high during the summer period, as indicated by the poor condition of the host-plant leaves. The total percentage of caterpillar mortality was high $(45.25 \%)$ in comparison with the mortality of eggs and pupae. However, only $5.59 \%$ of the dead caterpillars showed mycoses symptoms. Perhaps this could be the result of host-plant leafs, as it is known that the leaves of A. hippocastanum contain defensive substances (anthocyanins, phenols and flavonols) which might reduce the body mass and survival of caterpillars within leaf tissues [46,47].

The data obtained on fungi related to C. ohridella revealed 27 species from 19 genera, including eight species of entomopathogenic fungi, seven species of secondary (opportunistic) fungal pathogens and 12 species of saprotrophic fungi (Table 1). Common insect pathogens prevailed in the adult and pupal cadavers, comprising $65 \%$ and $46 \%$ of all isolates, respectively. A comparable proportion of the generalist entomopathogens was revealed in eggs (38\%) and caterpillars (28\%).

Depending on the moth development stage, the prevailing fungus species detected differed (except for the caterpillar stage, where the detection rate of any of 15 species varied from $2.77 \%$ to $13.89 \%$ only). At the egg stage, mycoses were mainly caused by Cladosporus cladosporioides (30.68\% of all mycoses), at the pupa stage Cordyceps fumosorosea and Beauveria bassiana prevailed (17.49\% and $16.94 \%$, respectively), and Lecanicillum aphanocladii (39.45\%) prevailed at the adult stage. The latter fungus species was recorded for the first time in Lithuania, and thus its identification was checked and confirmed by application of molecular methods and published in a separate paper [48].

Among entomopathogenic species, L. aphanocladii $(28.30 \%)$, B. basssiana $(24.06 \%)$, L. psalliotae $(17.93 \%)$ and C. fumosorosea $(17.45 \%)$ were the most abundant (Table 2). Information on the variety of entomopathogenic fungi involved in C. ohridella mortality is very scarce. Investigations of moth-related fungi and possible fungal pathogens have been performed in the Czech Republic [26-30]. Positive insecticidal effects of L. muscarium (Petch) Zare and W. Gams against C. ohridella caterpillars [33,34] and pupae [32] were reported. Cordyceps fumosorosea (syn., Isaria fumosorosea or Paecilomyces fumosoroseus), B. bassiana, and M. anisopliae were demonstrated to be pathogenic to the invasive moth as well [31-34].

Some opportunistic fungi were abundant as generalist fungal entomopathogens. They comprised $48 \%$ and $33 \%$ of the total number of fungi isolated from the C. ohridella eggs and caterpillars, respectively. Cladosporium cladosporioides and T. roseum species were the opportunistic fungal pathogens most often recovered. We found the latter fungi to be common on A. hippocastanum foliage (data not presented); thus we predict that direct contact could be the reason of the high infection of $C$. ohridella eggs. Sarocladium strictum was common among isolates from caterpillar and pupal cadavers as well. The fungus is known as the most common fungal endophyte of grasses, has been found on leaf surfaces of vascular plants, was frequently observed on other primary fungal colonizers like rusts or powdery mildews, and is widely distributed in the atmosphere [43]. The species is also known as related to the attack on insects $[49,50]$.

Comparative laboratory tests demonstrated (see Figure 2) that the L. aphanocladii entomopathogenic efficacy towards C. ohridella is equivalent to other well-known ento- 
mopathogens: C. fumosorosea, B. bassiana and L. psalliotae. No statistically significant difference was found between the pathogenic potentials of B. bassiana and C. fumosorosea. Although both fungi increased the mortality of eggs and naked pupae by up to $53.13-65.28 \%$, their induced mortality of pupae inside their mines (34.29-46.57\%) was significantly lower than the mortality induced by L. aphanocladii and L. psalliotae (53.11-56.82\%). A surprisingly high difference was revealed in the pathogenic potential of the species within the same Lecanicillium genus. Like L. aphanocladii, L. psaliotae conidia were highly pathogenic to naked pupae, but not to eggs. Based on the results of the present investigation, it cannot be firmly stated that L. aphanocladii was the strongest inhibitor of $C$. ohridella development; data on the comparative bioassay of the four fungi tested did not reveal significant interspecific pathogenicity differences, except at the egg stage, when L. aphanocladii was the most active. In conclusion, L. aphanocladii was commonly recovered from C. ohridella cadavers and showed high pathogenic potential in the bioassay. The fungus was found to be associated with A. hippocastanum foliage and was particularly common on the leaf surfaces with a higher density of powdery mildew disease inducing fungus, Erysiphe fexuosa (Peck) U. Braun and S. T. Takamatsu (syn. Uncinula flexuosa) (data not presented). We hypothesize that $L$. aphanocladii is related to E. flexuosa development, like three other closely related Lecanicillium species (L. attenuatum, L. lecanii (now renamed Akanthomyces lecanii) and L. longisporum), which are known to be active both against some insects and powdery mildew [51,52]. One more fungus species of the same genus, known as generalist mycoparasite, L. muscarium (formally known as V. lecanii) inhibiting powdery mildew [53], was discovered and confirmed as a C. ohridella pathogen [34]. This indicates that investigation of L. aphanocladii's relationship with other fungal species could offer perspective and provide more opportunities to develop environment-friendly methods for $C$. ohridella pest control by means of entomopathogens.

\section{Conclusions}

The total mortality of the leaf-miner horse-chestnut pest, Cameraria ohridella, collected in nature, and the mortality associated with mycoses, was assessed under laboratory conditions for eggs $(9.78 \%$ and $61.97 \%$, respectively) for caterpillars ( $45.25 \%$ and $5.59 \%$, respectively) and for pupae ( $21.22 \%$ and $100 \%$, respectively). At the egg stage, Cladosporus cladosporioides caused mycosis most often ( $27 \%$ of all mycoses); at the caterpillar stage there was no pronounced predominant fungus species; at the pupal stage both Cordyceps fumosorosea and Beauveria bassiana were dominant ( $32 \%$ and $31 \%$, respectively); and the adult stage Lecanicillum aphanocladii was dominant $(43 \%)$. C. ohridella moths remained the most vulnerable during the pupal and caterpillar stages. Maximum diversity of fungi associated with the leaf-miner moth was reached during the period of development inside the chestnut leaf (Shannon-Wiener index, $H^{\prime}=2.608$ at the caterpillar stage and $H^{\prime}=2.619$ at the pupal stage), whereas it reached a minimum at the adult stage $\left(H^{\prime}=1.757\right)$. Comparative laboratory tests revealed novel properties of the fungus $L$. aphanocladii, its effectiveness as the leaf-miner moth's entomopathogen and its suitability for field application trials while developing environment-friendly methods needed for horse-chestnut pest control.

Author Contributions: Investigation-D.P., I.N.; conceptualization-V.B.; methodology-D.P., writing—original draft, D.P., I.N.; writing—review and editing, I.N., V.B. All authors have read and agreed to the published version of the manuscript.

Funding: This research was funded by the European Social Fund/European Regional Development Fund under a grant agreement with the Research Council of Lithuania (LMTLT), grant number 09.3.3-LMT-K-712-01-0099, and the Article Processing Charges (APC) was funded by 09.3.3-LMT-K712-01-0099 and the Institute of Biosciences.

Institutional Review Board Statement: Not applicable.

Data Availability Statement: The data presented in this study are available on request from the corresponding author. 
Acknowledgments: The technical assistance of Vaidilute Dirginčiutè-Volodkienè (Institute of Botany, Nature Research Centre, Vilnius, Lithuania) is highly appreciated.

Conflicts of Interest: The authors declare no conflict of interest.

\section{References}

1. Backhaus, G.F.; Wulf, A.; Kehr, R.; Schröder, T. Die Rosskastanien-Miniermotte (Cameraria ohridella): Biologie, Verbreitung und Gegenmassnahmen. Nachrichtenbl. Deut. Pxanzenschutzd. 2002, 54, 56-62.

2. Gilbert, M.; Grégoire, J.C. Visual, semi-quantitative assessments allow accurate estimates of leafminer population densities: An example comparing image processing and visual evaluation of damage by the horse chestnut leafminer Cameraria ohridella (Lep., Gracillariidae). J. Appl. Entomol. 2003, 127, 354-359. [CrossRef]

3. Heitland, W. Controcam-control of Cameraria. Nachr. Dtsch. Pflanzenschutzd. 2006, 58, 251-252.

4. Heitland, W.; Kopelke, J.P.; Freise, J.; Metzger, J. Ein Kleinschmetterling erobert Europa-die Rosskastanien-Miniermotte Cameraria ohridella. Nat. Mus. 1999, 129, 186-195.

5. Syeryebryennikov, B. Ecology and Control of Horse Chestnut Leaf Miner (Cameraria Ohridella); Shmalhausen Institute of Zoology: Kiev, Ukraine, 2008; pp. 1-67.

6. Lees, D.C.; Lack, H.W.; Rougerie, R.; Hernandez-Lopez, A.; Raus, T.; Avtzis, N.D.; Augustin, S.; Lopez-Vaamonde, C. Tracking origins of invasive herbivores through herbaria and archival DNA: The case of the horse-chestnut leaf miner. Front. Ecol. Environ. 2011, 9, 322-328. [CrossRef]

7. Ivinskis, P.; Rimšaitè, J. The horse-chestnut leafminer (Cameraria ohridella Deschka \& Dimic 1986) (Lepidoptera, Gracillariidae) in Lithuania. Acta Zool. Litu. 2006, 16, 323-327. [CrossRef]

8. Stankevičienè, A.; Snieškienè, V.; Lugauskas, A. Erysipher flexuosa-The new pathogen of Aesculus hippocastanum in Lithuania. Phytopathologia 2010, 56, 67-71. Available online: https://hdl.handle.net/20.500.12259/50256 (accessed on 10 December 2020).

9. Valade, R.; Kenis, M.; Hernandez-Lopez, A.; Augustin, S.; Mari Mena, N.; Magnoux, E.; Rougerie, R.; Lakatos, F.; Roques, A.; Lopez-Vaamonde, C. Mitochondrial and microsatellite DNA markers reveal a Balkan origin for the highly invasive horse-chestnut leaf miner Cameraria ohridella (Lepidoptera, Gracillariidae). Mol. Ecol. 2009, 18, 3458-3470. [CrossRef]

10. Pschorn-Walcher, H. Freiland-Biologie der eingeschleppten Roßkastanien-Miniermotte Cameraria ohridella Deschka et Dimic (Lep., Gracillariidae) im Wienerwald. Linz. Biol. Beiträge 1994, 26, 633-642. Available online: https:/ /scholar.google.com/scholar? $\mathrm{hl}=1 \mathrm{t} \&$ as_sdt $=0 \% 2 \mathrm{C} 5 \& \mathrm{q}=$ Freiland-Biologie+der+eingeschleppten+Ro\%C3\%9Fkastanien-Miniermotte+Cameraria+ohridella+ Deschka+et+Dimic+\%28Lep.\%2C+Gracillariidae\%29+im+Wienerwald\&btnG= (accessed on 10 December 2020).

11. Skuhravý, V. Zur Kenntnis der Blattminen-Motte Cameraria ohridella Desch. \& Dim. (Lep., Lithocolletidae) an Aesculus hippocastanum L. in der Tschechischen Republik. Anz. Schädlingsk 1998, 71, 82-84. Available online: https://scholar.google.com/scholar? $\mathrm{hl}=1 \mathrm{t} \&$ as_sdt=0\%2C5\&q=Zur+Kenntnis+der+Blattminen-Motte+Cameraria+ohridella $+\& b t n G=($ accessed on 10 December 2020).

12. Šefrová, H.; Laštuvka, Z. Dispersal of the horse chestnut leafminer, Cameraria ohridella Deschka \& Dimic, 1986, in Europe: Its course, ways and causes (Lepidoptera: Gracillariidae). Zeitschrift Angew. 2001, 111, 194-198.

13. Freise, J.; Heitland, W. Bionomics of the horse-chestnut leaf miner Cameraria ohridella Deschka \& Dimic 1986, a pest on Aesculus hippocastanum in Europe (Insecta, Lepidoptera, Gracillariidae). Senckenb. Biol. 2004, 84, 61-80.

14. Girardoz, S.; Quicke, D.L.J.; Kenis, M. Factors favouring the development and maintenance of outbreaks in an invasive leaf miner Cameraria ohridella (Lepidoptera: Gracillariidae): A life table study. Agric. For. Entomol. 2007, 9, 141-158. [CrossRef]

15. Grabenweger, G.; Kehrli, P.; Schlick-Steiner, B.; Steiner, F.; Stolz, M.; Bacher, S. Predator complex of the horse chestnut leafminer Cameraria ohridella: Identification and impact assessment. J. Appl. Entomol. 2005, 129, 353-362. [CrossRef]

16. Grabenweger, G.; Hopp, H.; Schmolling, S.; Koch, T.; Balder, H.; Jäckel, B. Laboratory rearing and biological parameters of the eulophid Pnigalio agraules, a parasitoid of Cameraria ohridella. J. Appl. Entomol. 2009, 133, 1-9. [CrossRef]

17. Volter, L.; Kenis, M. Parasitoid complex and parasitism rates of the horse chestnut leafminer, Cameraria ohridella (Lepidoptera: Gracillariidae) in the Czech Republic, Slovakia and Slovenia. Eur. J. Entomol. 2006, 103, 365-370. [CrossRef]

18. Ferracini, C.; Alma, A. Evaluation of the community of native eulophid parasitoids on Cameraria ohridella Deschka and Dimic in Urban areas. Environ. Entomol. 2007, 36, 1147-1153. [CrossRef]

19. Péré, C.; Augustin, S.; Tomov, R.; Peng, L.H.; Turlings, T.C.J.; Kenis, M. Species richness and abundance of native leaf miners are affected by the presence of the invasive horse-chestnut leaf miner. Biol. Invasions 2010, 12, 1011-1021. [CrossRef]

20. Jagiełło, R.; Łakomy, P.; Łukowski, A.; Giertych, M.J. Spreading-the-risk hypothesis may explain Cameraria ohridella oviposition in relation to leaf blotch disease. Arthropod Plant Interact. 2019, 13, 787-795. [CrossRef]

21. Kehrli, P.; Lehmann, M.; Bacher, S. Mass-emergence devices: A biocontrol technique for conservation and augmentation of parasitoids. Biol. Control 2005, 32, 191-199. [CrossRef]

22. Baraniak, E.; Walczak, U.; Zduniak, P. Appearance and migration of the horse-chetnut leafminer Cameraria ohridella in relation to city size and leaf-raking, using the example of two cities in Western Poland. J. Pest. Sci. 2005, 78, 145-149. [CrossRef]

23. Ferracini, C.; Alma, A. How to preserve horse chestnut trees from Cameraria ohridella in the urban environment. Crop Prot. 2008, 27, 1251-1255. [CrossRef]

24. Kindl, J.; Kalinová, B.; Freise, J.; Heitland, W.; Augustin, S.; Guichard, S.; Avtzis, N.; Svatoš, A. Monitoring the population dynamics of the horse chestnut leafminer Cameraria ohrridella with a synthetic pheromone in Europe. Plant Prot. Sci. 2002, 38, 131-137. [CrossRef] 
25. Svatoš, A.; Kaliniová, B.; Hrdý, I. Cameraria ohridella: 10 years of sex pheromone and kairomone research. J. Appl. Entomol. 2009, 133, 319-327. [CrossRef]

26. Zemek, R.; Prenerova, E.; Weyda, F. The first record of entomopathogenic fungus Paecilomyces fumosoroseus (Deuteromycota: Hyphomycetes) on the hibernating pupae of Cameraria ohridella (Lepidoptera: Gracillariidae). Entomol. Res. 2007, 37, 135-136.

27. Zemek, R.; Prenerova, E.; Volter, L.; Weyda, F.; Skuhravy, V. Perspectives for the biological control of Cameraria ohridella. Commun. Agric. Appl. Biol. Sci. 2007, 72, 521-526.

28. Prenerova, E.; Zemek, R.; Weyda, F.; Volter, L. Sampling and occurrence of entomopathogenic fungi in soil from Cameraria ohridella (Lepidoptera: Gracillariidae) habitats. IOBS/WPRS Bull. 2008, 31, 204.

29. Prenerova, E.; Zemek, R.; Weyda, F.; Volter, L. Entomopathogenic fungi isolated from soil in the vicinity of Cameraria ohridella infested chestnut trees. IOBC/WPRS Bull. 2009, 45, 321-324.

30. Awad, M.; Prenerova, E.; Volter, L.; Zemek, R. Evaluation of Isaria funosorosea CCM 8367 for control of Cameraria ohridella, and effects on beneficial parasitoids. In Proceedings of the 43rd Annual Meeting of the Society for Invertebrate Pathology, Trabzon, Turkey, 11-15 July 2010. 138p.

31. Richter, D.; Sermann, H.; Jäckel, B.; Büttner, C.B. Pathogenicity of entomopathogenic fungi on hibernating pupae of Cameraria ohridella Ceschka \& Dimic 1986 (Lepidoptera, Gracillariidae). Part 1: Pathogenicity against the naked pupa. Commun. Agric. Appl. Biol. Sci. 2007, 72, 399-410. Available online: https://europepmc.org/article/med/18399468 (accessed on 10 December 2020).

32. Richter, D.; Sermann, H.; Jäckel, B.; Büttner, C.B. Pathogenicity of entomopathogenic fungi on hibernating pupae of Cameraria ohridella Descha \& Dimic 1986 (Lepidoptera, Gracillariidae). Part 2: Efficacy of entomopathogenic fungi against pupa in her pupas cell. Commun. Agric. Appl. Biol. Sci. 2007, 72, 411-421. Available online: https://europepmc.org/article/med/18399469 (accessed on 10 December 2020).

33. Kalmus, M.; Sermann, H.; Lerche, S.; Büttner, C. Efficiency of the entomopathogenic fungus Lecanicillium muscarium on hibernating pupae of Cameraria ohridella Descha \& Dimic, 1986 (Lepidoptera, Gracillariidae). IOBS/WPRS Bull. 2008, 31, $223-227$.

34. Lerche, S.; Sermann, H.; Büttner, C. Persitence of the entomopathogenic fungus Lecanicillium muscarium Zare \& Gams under ambient conditions in the field. Commun. Agric. Appl. Biol. Sci. 2009, 74, 353-356. [PubMed]

35. Schemmer, R.; Chládeková, P.; Medo, J.; Barta, M. Natural prevalence of entomopathogenic fungi in hibernating pupae of Cameraria ohridella (Lepidoptera: Gracillariidae) and virulence of selected isolates. Plant Protect. Sci. 2016, 52, 199-208. [CrossRef]

36. Gams, W. Cephalosporium-Artige Schimmelpilze (Hyphomycetes); Gustav Fisher Verlag: Stuttgart, Germany, 1971; 262p.

37. Samson, R.A. Paecilomyces and Some Allied Hyphomycetes; Studies in Mycology; Centraalbureau voor Schimmelcultures: Baarn, The Netherlands, 1974; Volume 6,119p.

38. Matsushima, T. Icones Microfungorum a Matsushima Lectorum; Takashi Matsushima: Kobe, Japan, 1975; 209p.

39. Pitt, J.I. A Laboratory Guide to Common Penicillium Species; Commonwealth Scientific and Industrial Research organization, Division of Food Research: Canberra, Australia, 1985; 122p.

40. Kiffer, E.; Morelet, M. The Deuteromycetes, Mitosporic Fungi: Classification and Generic Keys; Science Publishers Inc.: Enfield, CT, USA, 2000; 274p.

41. Zare, R.; Gams, W. A revision of Verticillium section Prostrata IV. The genus Lecanicillium and the new genus Simplicillium. Nova Hedwig. 2001, 73, 1-50. Available online: https://www.cabdirect.org/cabdirect/abstract/20023039635 (accessed on 10 December 2020).

42. Sung, G.H.; Hywel-Jones, N.L.; Sung, J.M.; Luangsa-ard, J.J.; Shrestha, B.; Spatafora, J.W. Phylogenetic classification of Cordyceps and the clavicipitaceous fungi. Stud. Mycol. 2007, 57, 1-64. [CrossRef] [PubMed]

43. Domsch, K.H.; Gams, W.; Anderson, T.H. Compendium of Soil Fungi, 2nd ed.; IHW-Verlag: Eching, Germany, 2007; Volume 2, 672p. [CrossRef]

44. Krebs, C.J. Ecological Methodology; Harper and Row Publisher: New York, NY, USA, 1989; 645p.

45. Girardoz, S.; Tomov, R.; Eschen, R.; Quicke, D.L.J.; Kenis, M. Two methods to assess the mortality factors affecting larvae and pupae of Cameraria ohridella in leaves of Aesculus hippocastanum in Switzerland and Bulgaria. Bull. Entomol. Res. 2007, 97, 445-453. [CrossRef] [PubMed]

46. Paterska, M.; Bandurska, H.; Wysłouch, J.; Molińska-Glura, M.; Moliński, K. Chemical composition of horse-chestnut (Aesculus) leaves and their susceptibility to chestnut leaf miner Cameraria ohridella Deschka \& Dimić. Acta Physiol. Plant. 2017, 39, 1-16. [CrossRef]

47. Jagiełło, R.; Baraniak, E.; Guzicka, M.; Karolewski, P.; Łukowski, A.; Giertych, M.J. One step closer to understanding the ecology of Cameraria ohridella (Lepidoptera: Gracillariidae): The effects of light conditions. Eur. J. Entomol. 2019, 116, 42-51. [CrossRef]

48. Pečiulytè, D.; Kačergius, A. Lecanicillium Aphanocladii-A New Species to the Mycoflora of Lithuania and a New Pathogen of Tree Leaves Mining Insects. Bot. Lith. 2012, 18, 133-146. [CrossRef]

49. Vidal, S. Changes in suitability of tomato for whiteflies mediated by a non-pathogenic endophytic fungus. Entomol. Exp. Appl. 1996, 80, 272-274. [CrossRef]

50. Jallow, M.F.A.; Gobena, D.D.; Vidal, S. Influence of an endophytic fungus on host plant selection by a polyphagous moth via volatile spectrum changes. Arthropod Plant Interact. 2008, 2, 53-62. [CrossRef]

51. Askary, H.; Carriere, Y.; Belanger, R.R.; Brodeur, J. Pathogenicity of the fungus Verticillium lecanii to aphids and powdery mildew. Biocontrol. Sci. Technol. 1998, 8, 23-32. [CrossRef] 
52. Kim, J.J.; Goettel, M.; Gillespie, D.R. Potential of Lecanicillium species for dual microbial control of aphids and the cucumber mildew fungus Sphaerotheca fuligena. Biol. Control 2007, 40, 327-332. [CrossRef]

53. Heintz, C.; Blaich, R. Ultrastructural and histochemical studies on interactions between Vitis vinifera L. and Uncinula necator (Schw.) Burr. New Phytol. 1990, 115, 107-117. [CrossRef] 